\title{
Effects of a Large Irrigation Reservoir on Aquatic and Riparian Plants: A History of Survival and Loss
}

\author{
Francisca C. Aguiar *(D), Maria Rosário Fernandes $₫$, Maria João Martins $₫$ and \\ Maria Teresa Ferreira \\ Centro de Estudos Florestais, Instituto Superior de Agronomia, Universidade de Lisboa, Tapada da Ajuda, \\ 1349_017 Lisboa, Portugal; mrfernandes@isa.ulisboa.pt (M.R.F.); mjmartins@isa.ulisboa.pt (M.J.M.); \\ terferreira@isa.ulisboa.pt (M.T.F.) \\ * Correspondence: fraguiar@isa.ulisboa.pt
}

Received: 7 October 2019; Accepted: 11 November 2019; Published: 14 November 2019

\begin{abstract}
Dammed rivers have unnatural stream flows, disrupted sediment dynamics, and rearranged geomorphologic settings. Consequently, fluvial biota experiences disturbed functioning in the novel ecosystems. The case study is the large irrigation reservoir Alqueva in Guadiana River, Southern Iberia. The study area was divided into three zones: upstream and downstream of the dam and reservoir. For each zone, species composition and land use and land cover (LULC) were compared before and after the Alqueva Dam implementation. Data consist of aquatic and riparian flora composition obtained from 46 surveys and the area (\%) of 12 classes of LULC obtained in 90 riverine sampling units through the analysis of historical and contemporary imagery. There was an overall decrease of several endemic species and on the riparian shrublands and aquatic stands, although differences in the proportion of functional groups were not significant. Nevertheless, compositional diversity shows a significant decline in the upstream zone while landscape diversity shows an accentuated reduction in the reservoir area and downstream of the dam, which is likely related to the loss of the rocky habitats of the 'old' Guadiana River and the homogenization of the riverscape due to the irrigation intensification. The mitigation of these critical changes should be site-specific and should rely on the knowledge of the interactions between surrounding lands, ecological, biogeomorphologic, and hydrological components of the fluvial ecosystems.
\end{abstract}

Keywords: Alqueva Dam; diversity; endemic species; Guadiana River; impacts; Mediterranean rivers; riparian trees and shrubs; riverscape change; species composition

\section{Introduction}

Rivers and humans compete for territory, water, and ecological resources. Dams are undoubtedly one of the major factors that unbalance those disputing relationships by threatening the fluvial ecosystem structure, processes, and functioning [1-3]. Damming affects river hydrology in quality, quantity, and timing; interrupts the longitudinal connection of habitat patches; and, consequently affects fluvial plant species distribution and biodiversity $[4,5]$. Downstream of dams, the impacts are manifold, including sediment depletion and rearrangement of the biogeomorphological stream components [6-9]. Several studies showed that the reduction of water flow and sediment downstream of the dam promotes changes in distinct biological communities, such as fish and invertebrates (e.g., [10-12]). The modification of the natural hydrologic regime depends on the technical characteristics of dams and on their operation rules and impacts the aquatic and riparian ecosystems differently in composition and spatial distribution [13-15]. For instance, diverse growth trajectories of riparian vegetation were observed in Mediterranean rivers impaired by different hydropower dam types [16]. Rivers downstream of storage reservoirs experienced mostly vegetation encroachment and expansion in the 
area toward the active channel by colonization of in-stream banks; whereas, in the run-of-river case study, riparian vegetation mostly expands outward toward the floodplain. These riparian formations likely lose the natural ecological succession phases due to lack of morphodynamic disturbance, i.e., the surface flow-derived processes that cause physical vegetation damage, sediment burial or uprooting, and entrainment [17]. There is also evidence that the absence of large floods in regulated rivers tends to favor aquatic and riparian species that do not require flood disturbances to disperse, establish, and grow, with consequences for the entire aquatic and riparian ecosystems $[9,14,18]$. The backwater effect of dams produces ponding in upstream segments up to a certain extension, and river dynamics experiences abrupt changes from a lotic system to the lentic environment of the reservoir. The impacts of backwater fluctuation on biogeomorphic succession cycles and vegetation zonation are less documented than downstream effects are. However, understanding the involved processes and vegetation feedbacks remains a challenge of multidisciplinary research [19].

Land-use and land-cover (LULC) is also an important factor to be taken into consideration when exploring the effects that damming has on a fluvial system and on the surrounding lands, either at a catchment or segment scale [20]. Dams alter LULC directly in the short-term through river engineering works and necessary infrastructures such as dam walls, or via flooding of nearby lands for the reservoir. In addition, enduring changes in the land-use of surrounding areas take place in the long term, especially if the dam's purpose is primarily for irrigation [21]. In this case, it is likely to observe rapid transitions in LULC toward intensive agricultural land-use and irrigation croplands [22].

The ambition of making drylands wetter in arid and semi-arid regions of the world has driven the construction of large watercourse infrastructures for irrigation purposes turning Mediterranean Europe into one of the most dammed regions of the world [2,23]. One of the most astonishing examples of landscape transformation in the Mediterranean Basin took place in the Alentejo region, Southern Portugal, with the construction of the Alqueva Dam in the Guadiana River. The dam creates the largest artificial lake in Europe at the maximum storage capacity with an area of $250 \mathrm{~km}^{2}$, more than $1100 \mathrm{~km}$ of shoreline, and a total capacity of $4150 \mathrm{hm}^{3}$. The reservoir occupies $83 \mathrm{~km}$ of the main watercourse. The Alqueva Multipurpose Project was built with the intention of regional development, through irrigation, industry, and energy production [24], but the effects on society, environment, and economy are still being evaluated, and the use of the European Union and national investments are still largely controversial [25]. The Albufeira Convention, a transnational agreement between Portugal and Spain signed in 1998 and further revised in 2008, established that minimum flows for the Guadiana River are established in relation to the amount of rainfall and water-stored in reservoirs in different trimesters of the year. Minimum daily flows of $2 \mathrm{~m}^{-3} \mathrm{~s}^{-1}$ are set up in exceptional drought periods. Besides the Alqueva Dam, the project plan includes 68 reservoirs and pumping stations and around $5000 \mathrm{~km}$ of irrigation channels. Following the implementation of the project, there was direct loss of habitat by land flooding, and by the removal of around 1.5 million trees. The Natura 2000 (European nature conservation network) Juromenha-Guadiana site was partially lost, as well as the habitat of many endangered flora and fauna species, such as the endemic fern Lusitanian water clover (Marsilea batardae), the Iberian lynx, (Lynx pardinus), the wild cat (Felis silvestris), the black stork (Ciconia nigra), and the saramugo (Anaecypris hispanica), just to name a few [26,27]. A decline in the abundance of steppe birds was documented [28], as well as changes in the composition of dragonfly communities [29]. Landscape changes, shifts in habitats, and loss of biodiversity were already documented, but they are mainly in estuarine areas, related to ichthyofauna $[11,30,31]$ or to the water quality of the reservoir (e.g., [32,33]). Flora and vegetation of the Guadiana River basin was the object of several field campaigns and studies before the Alqueva Dam implementation (e.g., [27] or [34-41]). However, as far as we know, studies on dam-induced alterations on aquatic and riparian vegetation post-Alqueva are scattered and mostly focused on priority species. The main goal of the present study is to compare the pre-dam and post-dam aquatic and riparian vegetation composition, diversity, and riverine landscape changes in three zones of the Guadiana River, upstream and downstream of the dam and reservoir. 
Our specific objectives were to (i) explore how the post-dam aquatic and riparian vegetation differ from the pre-dam ones in relation to species richness, composition, and functional characteristics; (ii) evaluate the riverscape change in terms of land use and land cover and aquatic and riparian patches; (iii) assess the losses/gains on spatial (landscape) and compositional (floristic) diversity.

Our predictions were that: (1) post-dam aquatic and riparian zones are floristically different from the pre-dam landscapes, with a generalized loss of aquatic plant species (endemic and native), relating to the gain of exotic and ruderal species, and (2) there was a decline in compositional and landscape diversity. Overall, it is our aim to provide warnings on the critical issues relating to the aquatic and riparian flora and landscape change of the Guadiana River basin.

\section{Materials and Methods}

\subsection{Study Area}

The study area comprises the main course of the Portuguese part of the Guadiana River, in Southeastern Portugal, from the Spanish border to "Pulo do Lobo Anticlinory Formation" (Figure 1). The Guadiana River is one of the large transboundary rivers of the Iberian Peninsula, flowing North-South for around $150 \mathrm{~km}$ from the Spanish border toward the Gulf of Cádiz, in the Atlantic Ocean. The entire basin is $66,960 \mathrm{~km}^{2}$ out of which $11,700 \mathrm{~km}^{2}$ are on the Portuguese territory. The climate varies from sub-humid to dry and semi-arid, with hot (average annual temperature of $16{ }^{\circ} \mathrm{C}$ ) and dry summers (average annual rainfall of $550 \mathrm{~mm}$ ), high levels of insolation and evapotranspiration [42]. During the summer there is a scarce flow, usually followed by torrential fall and winter floods and then by a decrease of flow in the spring. Geologically, the Guadiana River basin lay on a Hercinic basement and it is typically formed out of metasedimentary and metavolcanic rocks, with calcareous intrusions and more recent deposits. The Alqueva Multipurpose Project was commissioned in 2002, irrigates about 120,000 ha of agricultural land, ensures water for public supply to 200,000 people, and produces enough hydroelectricity to supply a city with more than 500,000 inhabitants [43]. Besides the increase of the area of irrigation crops after the Alqueva Dam construction, the rainfed agriculture occupies more than 634,000 ha, of which about $66 \%$ are pastures for livestock grazing. The Guadiana River basin in Portugal covers 20 municipalities from four districts, with an overall 230,000 inhabitants (around 15 inhabitants $/ \mathrm{km}^{2}$ ) [43].

The land use in the Guadiana River basin is very heterogeneous, including wheat, grasslands and pastures, olive and almond groves, vineyards, as well as crops such as maize, rice, tomatoes, and sunflowers. Agroforestry is relevant in the area, with holm and cork oak production which are cultivated mainly on metasedimentary rocks; these rocks are also a substrate for Mediterranean scrubland. Unproductive land on slopes with stony soils are mainly covered with sclerophyllous Mediterranean shrubs. The area is home to around 100 species with conservation interest and many endemics $[37,44]$. Riparian vegetation typically includes evergreen woody species such as the oleander (Nerium oleander), African tamarisk (Tamarix africana) and the endemic species tamujo (Flueggea tinctoria). The ash (Fraxinus angustifolia) and diverse willows (genus Salix), including the Iberian endemism (Salix salviifolia), were also common along the riparian fringe of the main course of the Guadiana River and tributaries $[40,41]$.

\subsection{Sampling Design and Data}

\subsubsection{Floristic Data}

Floristic data for the period before the Alqueva Dam implementation, namely from 1987 to 1999, were obtained from 153 sampling surveys made by several collaborators of the Forest Research Centre, University of Lisbon, in the scope of diverse technical and research projects. These sampling surveys were then filtered using the following criteria: (i) location: Guadiana main watercourse or tributaries near the mouth; (ii) sampling area: $250 \mathrm{~m}$ long river reaches (iii) sampling season: late 
spring-early summer; (iv) geographic accuracy: known exact location of the survey; (v) number of surveys: existence of two or more surveys per location. From the overall 153 available sampling surveys, we selected 28 comparable historical surveys from nine locations, hereafter called 'core-sites'.

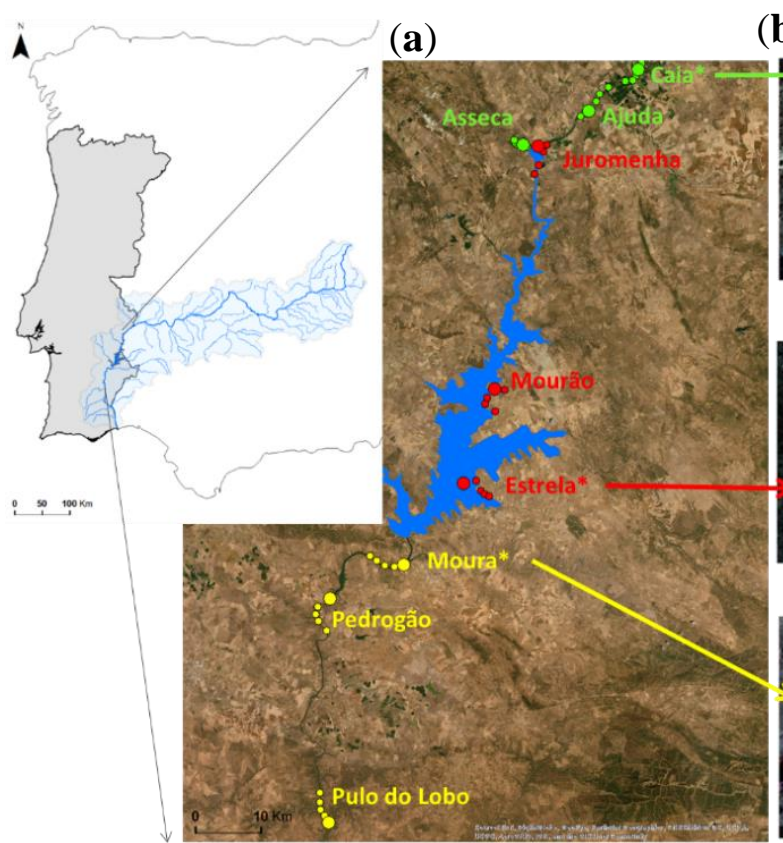

(b)
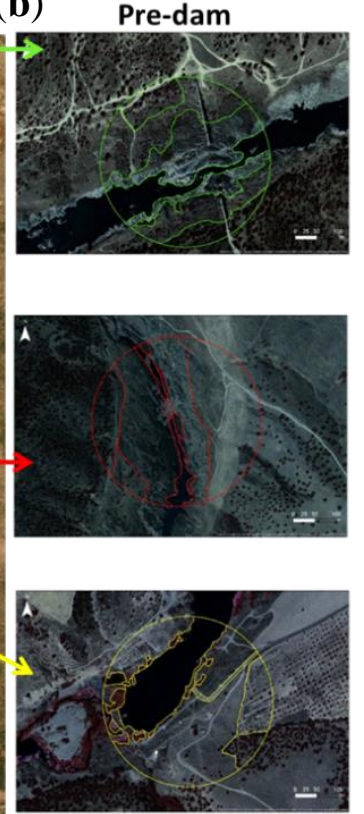

Post-dam
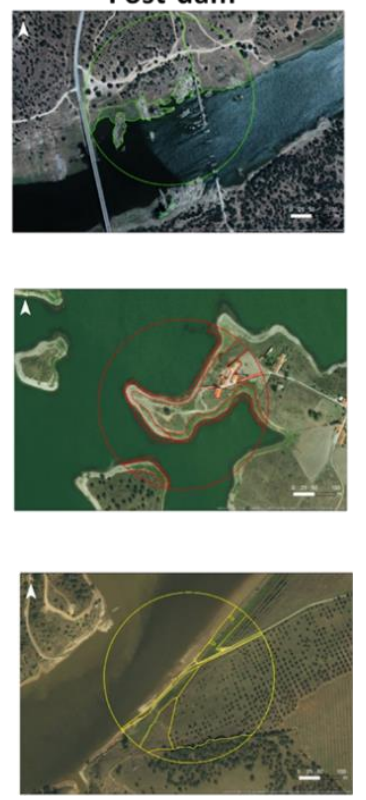

Figure 1. Geographical location of the Guadiana River Basin and river network in Spain and Portugal (a). Location of the circular sampling units ( $n=45$ in each period) in the studied zones (b). The six panels (right side) correspond to pre- and post-dam examples of the circular sampling units done on the same core-site (marked with $\mathrm{a}^{*}$ ). Locations in green = upstream of dam; locations in red = reservoir; locations in yellow $=$ downstream of dam.

Other research groups and EDIA S.A. (Empresa de Desenvolvimento e Infraestruturas do Alqueva), the company responsible for the design, execution, construction, and operation of the Alqueva Multipurpose Project, were contacted aiming to enlarge the number of surveys (pre- or post-dam). However, these efforts were unsuccessful due to a lack of analogous sampling methods.

The 28 surveys were located in three zones of the main watercourse of the Guadiana River with distinct impacts induced by the Alqueva Dam, namely Upstream of dam (influence of the backwater; core-sites-Caia, Ajuda, Asseca), Reservoir (flooded area; core-sites-Juromenha, Mourão, Estrela), and Downstream of the dam (low flooded area; core-sites-Moura, Pedrogão, Pulo do Lobo) (Figure 1). These pre-dam surveys were done in a $250 \mathrm{~m}$-long river stretch, which included the riverbank and the water in an extension of $15-20 \mathrm{~m}$ width $\left(3750-5000 \mathrm{~m}^{2}\right)$. All plants in the sampling area were recorded and identified at the species level, when possible. The percentage cover of each species in the overall total sampling area was taken as an estimation of species abundance.

For the post-Alqueva Dam period, we organized two field campaigns (2017 and 2018) to the nine core-sites and we used the same sampling methods that were done in the historical surveys, totalizing 18 surveys. Upstream and downstream core-sites were done on the exact geographical location, but for five core-sites that are presently flooded, i.e., positioned in the reservoir or affected by the flooding, the surveys were done at the shoreline of the reservoir aligned with the historical survey on the Guadiana River.

In total, the species matrix has 46 floristic surveys. We classified the recorded species into functional plant groups related to the physiognomy (four classes: trees, shrubs and lianas, herbs annual, herbs perennial), origin/disturbance (four classes: endemic, native, native ruderal, exotic), and species hydrophily (four classes: hydrophytes = aquatic plants sensu stricto, helophytes $=$ amphibious plants, hygrophytes $=$ prefer wet or shaded habitats, terrestrial). The species classification was done 
resourcing to national and Iberian floras (e.g., [45]). We calculated the species richness and computed the Shannon-Wiener Index $\left(\mathrm{H}^{\prime}\right)$ for all species recorded and all pre- and post-dam surveys $(1) . \mathrm{H}^{\prime}$ was referred to as 'Compositional Diversity'.

$$
\mathrm{H}^{\prime}=-\sum_{n=i}^{S} p i \ln p_{i},
$$

where $n_{i}$ is the species abundance, $S$ the total number of species in each site, $p_{i}$ is the relative abundance of each species, calculated by dividing ni by the total abundance of the species on the community.

\subsubsection{Spatial Data}

For the assessment of the riverine landscape change a temporal comparison using pre- vs. post-dam, high-resolution aerial orthophotos were obtained. All images were obtained from Direção-Geral do Território (http://www.dgterritorio.pt/). Contemporary images (post-Alqueva Dam) are true-color composite orthophotos (red-green-blue composition, $50 \mathrm{~cm}$ of spatial resolution) acquired during the spring of 2015 while pre-dam images are false-color composite orthophotos NIR (Near-infrared)-red-green composition, $1 \mathrm{~m}$ of spatial resolution) acquired during spring 1995.

A circular buffer with $200 \mathrm{~m}$, hereafter referred to as the circular sampling unit, was first positioned surrounding the center of each core-site in order to capture the LULC changes in the fluvial, the riparian, and the surrounding floodplain systems. Then, to improve the representativeness of the riverine landscape changes we additionally placed four circular sampling units, near each core-site. The circular sampling units were spread at least $500 \mathrm{~m}$ to avoid spatial autocorrelation in the data, totalizing 90 circular sampling units at the three zones of the river, and for the pre- and the post-Alqueva Dam periods (Figure 1). Inside the circular sampling units, we mapped and classified by on-screen photo interpretation 12 LULC areas divided into two categories: (1) Fluvial and riparian classes: water, islands, aquatic stands, riparian herbaceous vegetation, and riparian woods and (2) floodplain classes: forestry, agroforestry, shrublands, irrigation crops, urban areas, rock, bare ground. The total number of digitalized patches was 1522. We computed the area (ha) for each LULC class inside the sampling units using ArcGIS 10.5. We also computed the Shannon-Wiener Index $\left(\mathrm{H}^{\prime}\right)$ as an indicator of 'landscape diversity', where $\mathrm{n}$ is the number and the percentage of all landscape elements observed in each circular sampling unit, as richness and abundance, respectively.

\subsubsection{Statistical Analysis}

In order to detect changes in floristic composition before and after the Alqueva Dam (compositional analysis), species distribution (species proportion) across functional plant groups was compared between the two periods using a chi-square homogeneity test. The computations were performed with function chisq.test of R statistical software (R 3.4.4, 2018, Foundation for Statistical Computing, Vienna, Austria).

The change in vegetation cover between the two periods is visualized through radar charts obtained with R function radarchart from package fmsb (v0.6.3, M. Nakazawa, 2018).

The comparison of the proportion of area occupied by each LULC class (landscape analysis) in the two time periods was performed through $95 \%$ confidence intervals for mean differences. The same procedure was used to compare the landscape diversity. Computations were performed with $\mathrm{R}$ function $t$-test for paired samples. As the number of sample units of floristic data (field surveys) is not coincident in the pre- and post-dam periods, the compositional diversity was compared through a $95 \%$ confidence interval for the difference between means in independent samples. 


\section{Results}

\subsection{Species Richness and Floristic Composition Changes}

Altogether, we recorded 212 vascular plant species, specifically 183 species before the Alqueva Dam implementation, and 146 species in the contemporary surveys (pre-dam and post-dam hereafter, respectively).

We observed a decline in species numbers from the 'old' Guadiana River to the present landscape in all zones, but more pronounced in the reservoir zone (RES) (Figure 2). Specifically, there was a loss of around 53\% of the species at RES, while at the upstream (UP) and downstream zones (DOWN) the number of species losses was around $40 \%$ of the total species recorded. There were also differences across zones in 'species gains', that is, species solely recorded on the novel landscapes. RES zone gained fewer species in relation to the UP and DOWN zones. Only 15 new species were observed in RES ( $22 \%$ of total post-dam species recorded), followed by UP and DOWN zones, where these novel species contributed to around $24 \%$ and $29 \%$ of the total species list, respectively (Figure 2).
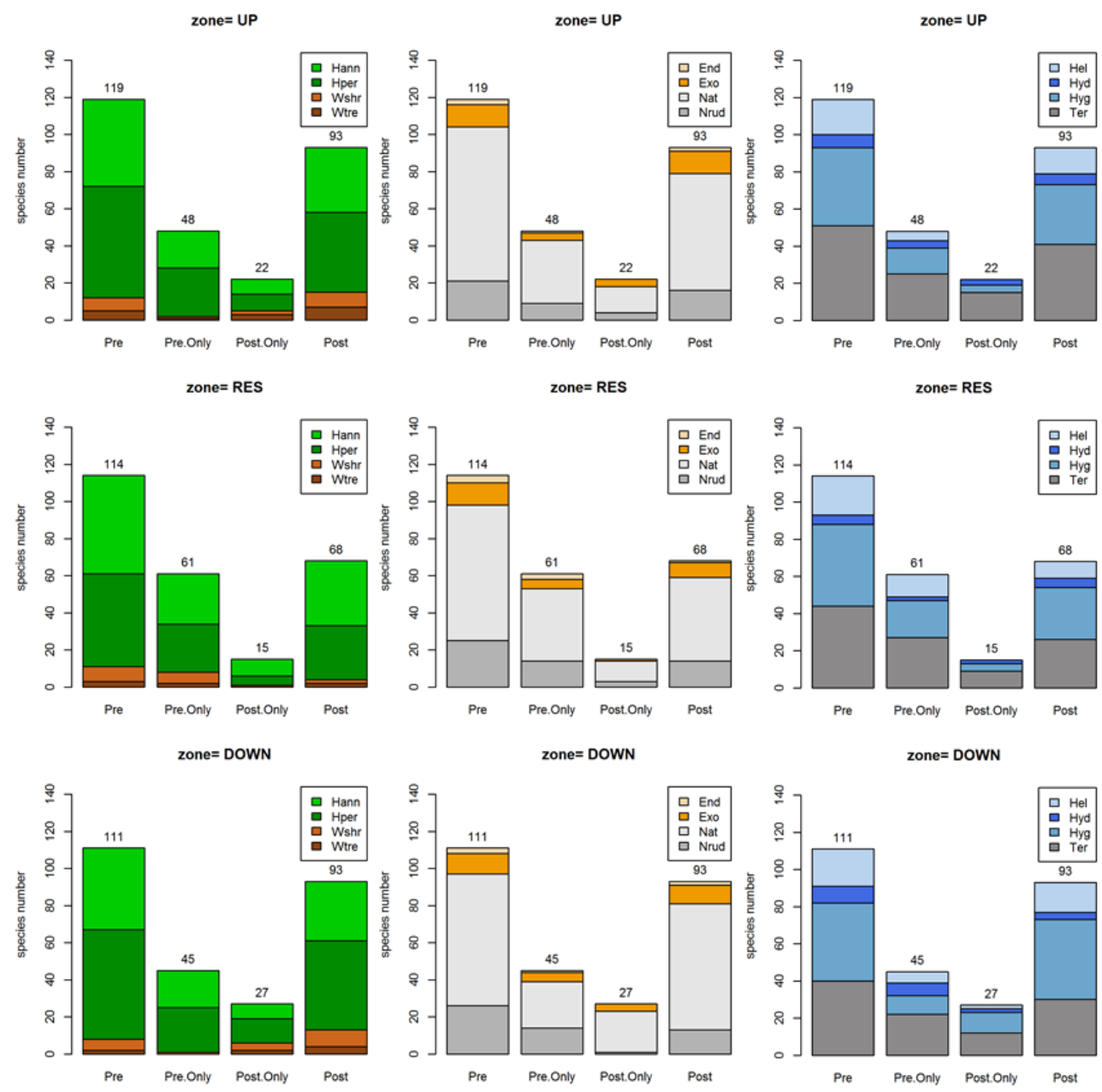

Figure 2. Number of species per functional group observed in pre-dam surveys, observed pre-dam but not post-dam (Pre.Only), observed in post-dam and not pre-dam (Post.Only), and in post-dam surveys. "Hann" = herbaceous annual species; "Hper" = herbaceous perennial species; "Wshr" = shrubs and lianas; "Wtre" = trees. Origin/disturbance: "End" = endemic species; "Exo" = exotic species; "Nat" = native species; and "Nrud" = native ruderals species. Species hydrophily: "Hel" = helophyte species; "Hyd" = hydrophyte species; "Hyg" = hygrophyte species; "Ter" = terrestrial species). Each column corresponds to a zone (UP = upstream of dam, RES = reservoir, and DOWN = downstream of dam). 
Though there was an overall decline of regional species richness from pre-dam to post-dam, all endemic species and all native woody species recorded pre-dam were observed in the post-dam field campaigns. However, the local species richness differed across the landscape, and several woody species (e.g., N. oleander, F. angustifolia) and endemic species (S. salviifolia, M. batardae, F. tinctoria) were not found in several locations in the post-dam landscape (Figure 3). F. tinctoria, for instance, was recorded in $68 \%$ of the surveys in the pre-dam period and only in $33 \%$ on the post-dam, and with much less cover abundance. F. angustifolia was found in almost all pre-dam surveys (93\%) but decreased the frequency of occurrence to $56 \%$ of the post-dam surveys. Likewise, S. salviifolia was absent from half of the sites and surveys whereas it was recorded in pre-dam field campaigns (Figure 3). In contrast, Rubus ulmifolius (elmleaf blackberry) increased its frequency of occurrence after the Alqueva Dam implementation.

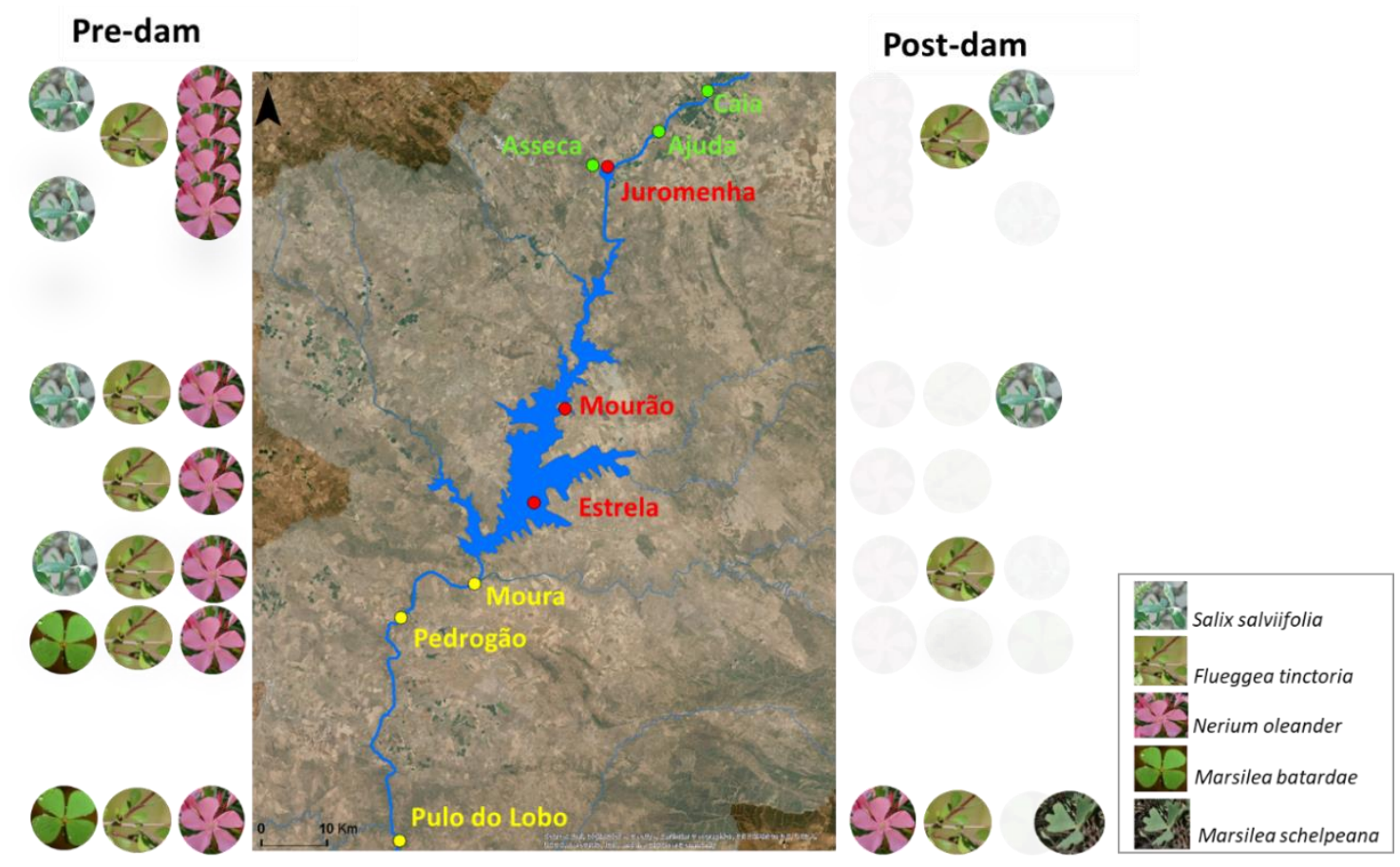

Figure 3. Illustration of species occurrence in core-sites of five species with conservation interest before (left side of the image) and after (right side of the image) the Alqueva Dam implementation. Location and names of core-sites are given. Locations in green = upstream of dam; locations in red = reservoir; locations in yellow $=$ downstream of dam.

We did not observe any population of $M$. batardae on the post-dam surveys (Figure 3). M. batardae is an Iberian endemic fern, with four characteristic clover-like leaflets, 'Endangered' according to the IUCN (International Union for Conservation of Nature) Red List of Threatened Species [46] and protected by the Habitats Directive (92/43/EEC) and conventions. It was included in the EDIA SA monitoring program [27,37]. Surprisingly, at the most distant downstream core-site-Pulo do Lobo-we found one population of Marsilea schelpeana on the field campaign of 2017. This species is an aquatic or semi-aquatic exotic plant, native from Eastern and Western Cape, South Africa, with IUCN status 'Vulnerable' [47]. It was the first national record of this species, and, as far as we know, the species was only recorded in South Africa (Global Biodiversity Information Facility, http://www.gbif.pt; accessed 22 September 2019). Specimens were collected and herborized at the LISI Herbarium (Herbário João Carvalho e Vasconcellos), School of Agriculture, University of Lisbon, Portugal. The population was recorded in the same location in 2018.

Likewise, several widespread helophyte species in pre-dam landscapes decreased the frequency of occurrence in the post-dam period, and especially in the RES area. That was the case of Eleocharis 
palustris, Scirpus lacustris, Phragmites australis, and Veronica anagalloides. However, the absence of species was not limited to the RES area. For instance, at the Asseca site (UP), the well-preserved riparian gallery of $F$. angustifolia previously observed in pre-dam times is currently formed by standing dead trees on the waterlogged riverbanks. The frequency of occurrence and cover abundance of oleander, African tamarisk, and the Iberian endemic shrubs F. tinctoria (tamujo) and S. salviifolia (borrazeira-branca) decreased after the Alqueva Dam implementation (Figure 3). Nevertheless, although in the most northern UP survey (Caia) the Salix increased in cover along the riverbanks.

The overall number of species recorded per site in pre-dam and post-dam periods increased, ranging from $31.9 \pm 9.4$ (average \pm standard deviation) to $36.1 \pm 7.9$, respectively. While the local richness on UP surveys remained almost unaltered (39.2 \pm 10.6 in pre-dam and $38.2 \pm 9.7$ in post-dam surveys), there was a decrease in RES zone ( $32.8 \pm 8.2$ to $28.8 \pm 2.3$ species) and the DOWN zone increased in the average number of species found per site ( $27.9 \pm 7.8$ to $41.3 \pm 1.7$ species).

\subsection{Functional Changes}

The chi-square homogeneity tests revealed that there were no significant differences in the proportions for all functional groups studied as shown in Table S1 (Supplementary Material). Both periods had more perennial herbaceous species than annual species, except in the RES zone. The number (and proportion) of woody species (trees and shrubs) in relation to herbs was small across the landscape. Changes in proportions of species by their origin (native, endemic, exotic) and ruderality, i.e., the plant's ability to survive in disturbed conditions, were insignificant. The two exceptions were in the DOWN zone, where proportions of native species increased and native ruderals decreased (Figure 2).

Overall, in both periods, there was a low number of hydrophytes (i.e., aquatic plants sensu stricto) and helophyte species (i.e., amphibious species) in relation to hygrophytes (plants associated with wet/shaded environments), and terrestrial species. Proportions of functionally diverse species in relation to hydrophily were not significantly different across zones and periods (Table S1). However, we noticed an increase of the proportions of hydrophytes in RES and a decrease in DOWN. There was also a noteworthy increase of hygrophytes downstream of the dam and a decrease of helophytes in the reservoir shoreline.

We illustrate in Figure 4 how species cover abundance changed from the pre-dam surveys to post-dam surveys in relation to functional groups. In general, we observe a clear reduction of vegetation cover after the Alqueva Dam implementation, which agrees with the relative cover of functional groups of the surveys within each zone that rarely surpasses the cover of pre-dam period.

In pre-dam times, the 'old' Guadiana had a higher woody species cover than the current landscape alongside a higher relative cover by annual herbs, except on Caia surveys, UP zone (Figure 4a). The overall reduction in woody cover abundance is mostly related to the Mediterranean shrublands (tamarisk, oleander, tamujo, and borrazeira-branca) that decreased from an average of ca. $33 \%$ to ca. $14 \%$. The RES is currently relatively more prone to occupation by exotic vegetation and holds less native and endemic vegetation cover (Figure $4 \mathrm{~b}$ ). Following the patterns of species numbers and proportion of hydrophytes (Figure 2), the RES and UP zones have more area covered by aquatic plants (Figure 4c). RES and DOWN zones were covered to a lesser extent by hygrophyte species in post-dam surveys, while the UP area has relatively more cover by hygrophytes and terrestrial species (Figure 4c). 

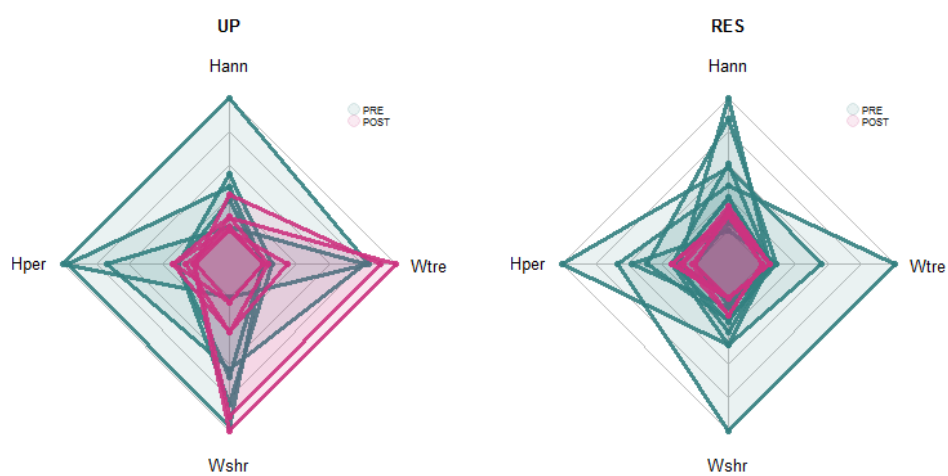

(a)
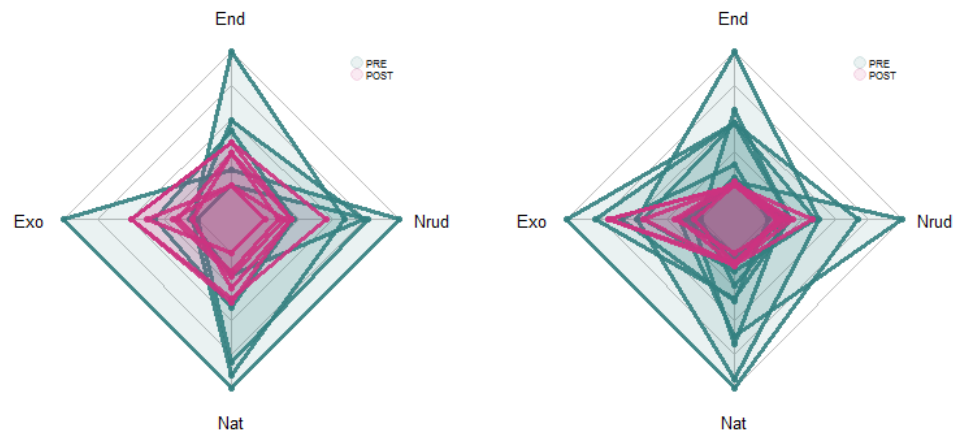

(b)
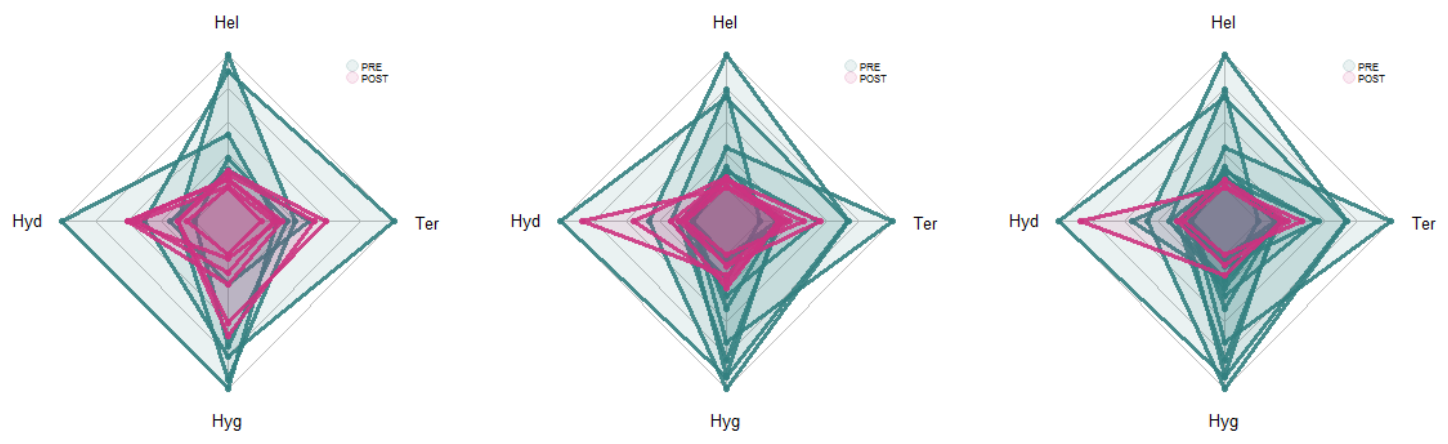

(c)
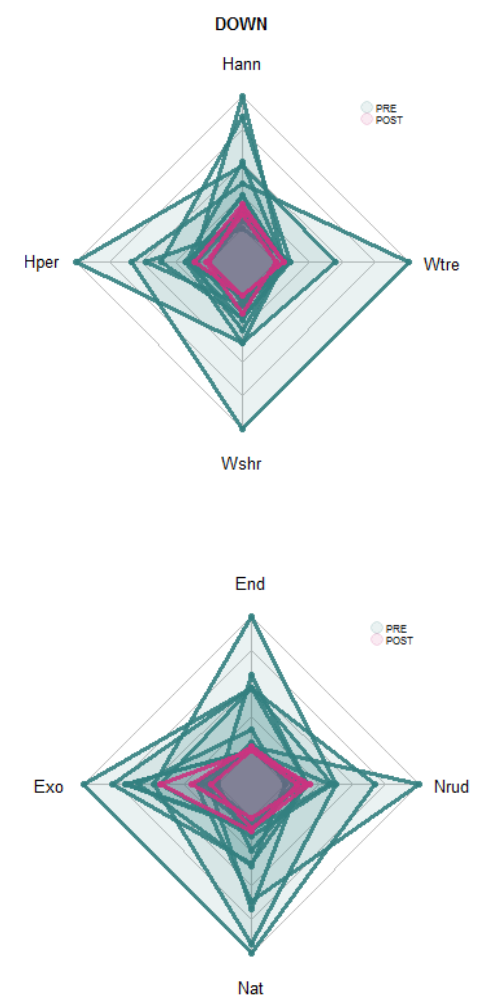

Figure 4. Radar charts for vegetation cover. Each line corresponds to a functional classification: (a) physiognomy; (b) origin/disturbance; (c) species hydrophily. Each column corresponds to a zone (UP = upstream of dam, RES = reservoir, and DOWN = downstream of dam). In each plot, lines join the percentage cover of the four groups in the same survey while colors distinguish the pre- and post-dam surveys (green for the pre-dam and pink for the post-dam). The scale is not the same between lines or between columns. Acronyms are given in the caption of Figure 3.

\subsection{Riverine Land Use and Land Cover Changes}

The analysis of the LULC data show that riverine landscapes have changed between the pre- and post-dam dates. Guadiana riverscapes are particularly different in the RES and DOWN zones when comparing the pre-dam with the post-dam date, which is likely related to the inundation of rocky habitats of the 'old' Guadiana river and with the increase in irrigation crops and urban uses (Figure 5). 

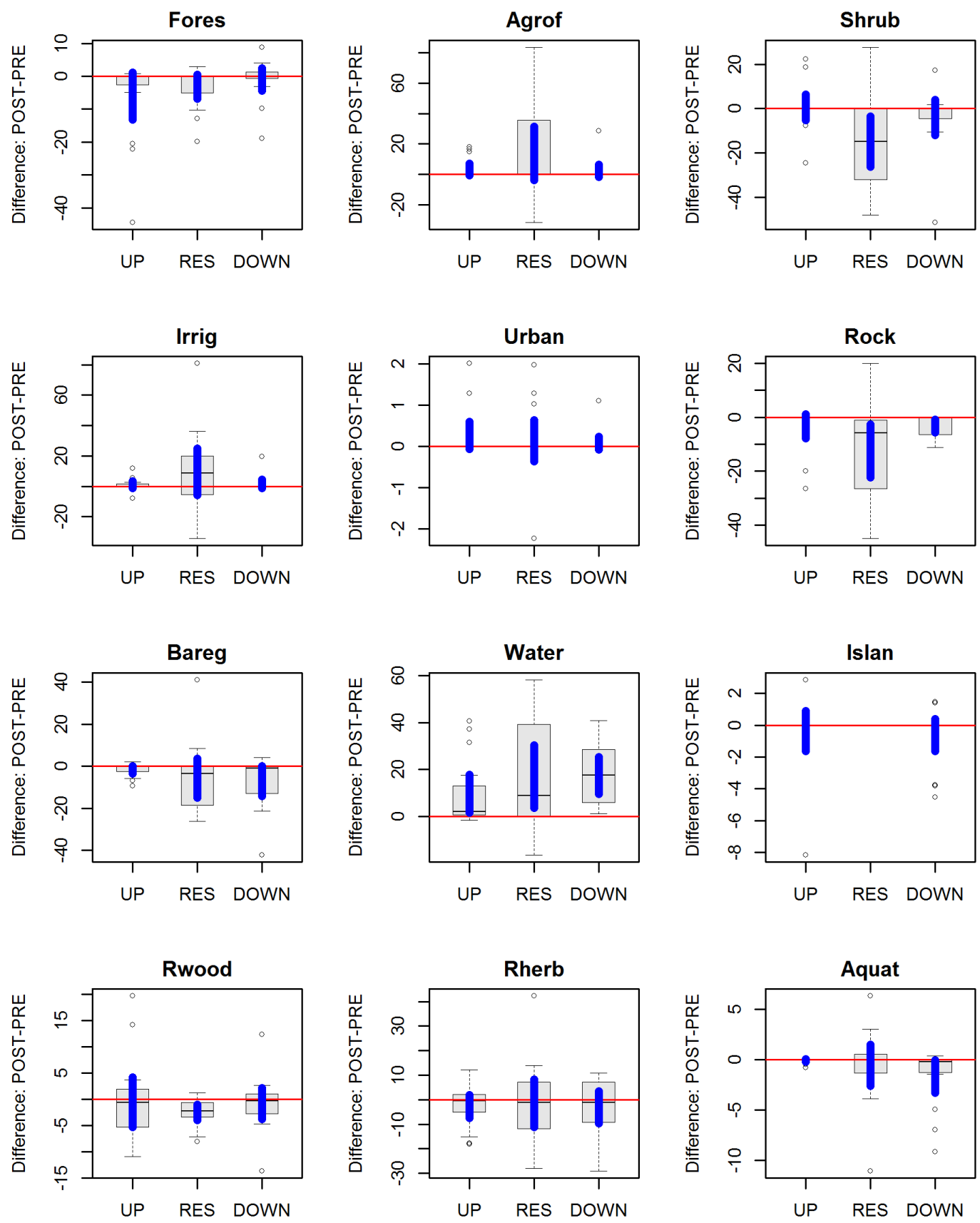

Figure 5. Boxplots for the differences between post- and pre-dam proportions in land cover. Each blue bar connects the lower and upper extremes of the $95 \%$ confidence interval for the means difference. Whenever the blue bar crosses the red line, the differences are not significantly different from zero at a $5 \%$ significance. Fores = forest plantations; Agrof = agroforestry $($ 'montado'); Shrub = shrublands; Irrig = irrigation crops; Urban = urban and industrial areas; Rock = bedrock; Barg = bare ground; Water = water; Islan = islands; Rwood = riparian woodlands; Rherb = riparian herbaceous stands; Aquat = aquatic plant stands.

We detected a statistically significant decline in the cover of Mediterranean shrublands ('Shrub') and the riverine woody cover in RES ('Rwood'), whereas the area occupied by riparian herbaceous stands ('Rherb') were not significantly different in the post-dam period for all the studied zones (Figure 5). The cover by freshwater ('Water') significantly increased in all zones. There was a noticeable increase of irrigation crops ('Irrig'), and agroforestry ('Agrof') in RES zones, and a decrease of riparian 
woodlands ('Rwood') in all zones, but mostly in RES and DOWN, in accordance with the results from the field (Figures 2-4).

\subsection{Compositional and Landscape Diversity}

The floristic composition is significantly more diverse downstream of the dam than before the dam implementation. The RES and UP zones show a decrease in compositional diversity, but only significantly different upstream of dam (Figure 6). In relation to the diversity of LULC, the landscape is significantly less diverse in the reservoir area and downstream of the dam and shows a similar pattern (but non-significant) on the UP zone, with a reduction of the landscape diversity. RES depicts a larger variation on the riverine landscape diversity values from all zones.

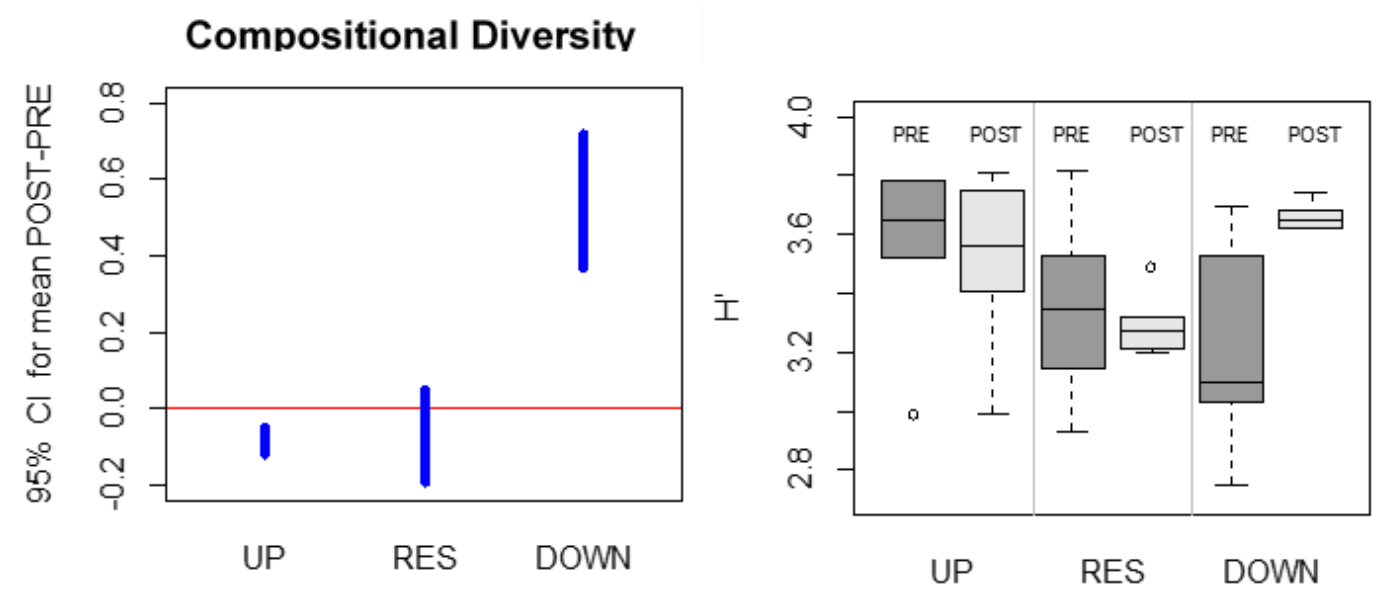

\section{Landscape Diversity}

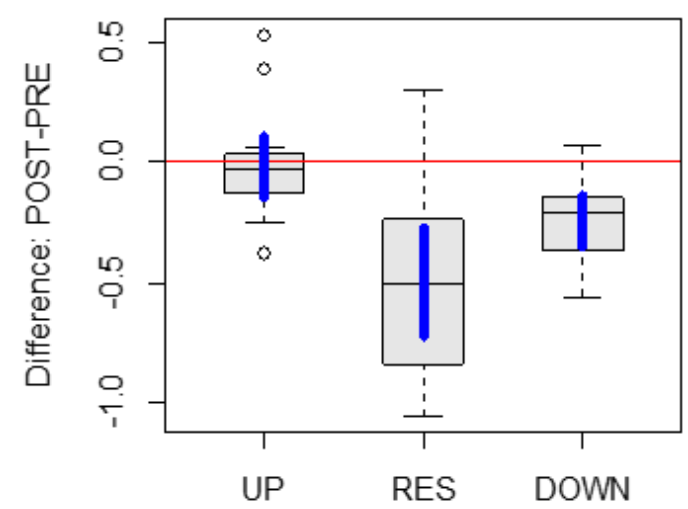

Figure 6. Boxplots for the differences between post- and pre-dam compositional diversity and for the landscape diversity before (PRE) and after dam implementation (POS) for each zone (UP = upstream of dam, RES = reservoir; DOWN = downstream of dam). Each blue bar connects the lower and upper extremes of the $95 \%$ confidence interval for the mean difference. Whenever the blue bar crosses the red line, the differences are not significantly different from zero at a $5 \%$ significance.

\section{Discussion}

A common prediction in fluvial and riverine landscapes disturbed by streamflow regulation and LULC change is that post-dam plant communities become richer in exotic species, more susceptible to plant invasions and more species-poor in endemic and native plants $[5,6]$. Building on this, our first prediction was that the post-dam aquatic and riparian zones are floristically different from the pre-dam landscapes, and that it could be linked to a generalized loss of plant species (endemic and native), and to a gain of exotic and ruderal species. In our study, we found that present-day 
communities at the Guadiana basin differ in species composition, with fewer native species. However, the overall landscape has maintained totals of endemic species, and no relevant gains of exotic species or higher proportions of ruderal species were observed. Biodiversity and ecosystem processes in these fragmented riverine landscapes are exposed to novel geomorphological settings and to habitat loss and variation in species communities was expected. The Guadiana basin has a long history of human disturbances, especially due to long-lasting agro-sylvo-pastoral uses, and previous research already identified species-poor communities and a high proportion of hygrophytes and terrestrial species and few helophytes and hydrophytes [36,37,40]. In addition, Mediterranean riverscapes are known as highly resilient ecosystems. In general, they recover rapidly from disturbances, and, at the landscape scale, fragmented ecosystems resort to patch dynamics to operate with dispersal of species between patches [48]. Nevertheless, our study demonstrated that alterations are clearly different between zones subjected to distinct impacts induced by the Alqueva Dam. The reservoir area was the most divergent zone from the pre-dam landscape, with a high number of local native and endemic species losses, great decline in riparian woodlands, and relatively higher proportion and cover of exotic species. Nonetheless, the field surveys done at the shoreline of the reservoir allowed us to discover some 'reliquial habitats' mostly composed of graminoid species, but woody species poor. The main recruitment processes—germination, seedling survival, and seedling growth-are essential for the recovery after disturbance [49]. Mechanisms underlying resilience are difficult and frequently need a detailed investigation at local habitat levels, as well as recruitment and survival that in many cases require conservation efforts, such as species translocations and active restoration of riparian vegetation $[41,49,50]$. Several fluvial processes may alter the vegetation establishment. For the upstream Guadiana region, groundwater abstraction for agriculture can be responsible for the rising salinity levels, and declines in groundwater levels, with consequences for plant establishment [51,52]. In these river reaches, overloading of water creates fine sediment deposition in banks and riverbed, altering water turbidity and temperature and, in consequence, causing the loss of aquatic plant communities adapted to lotic conditions and diverse mesohabitats. In contrast, it is known that besides the novel low-energy conditions, large dams have an extremely high efficiency of sediment trapping, which disturbs natural patterns of plant rooting by coarsening the riverbed downstream [53].

Alongside the native species declines, surprising shifts of congener species were found such as that of the endemic M. batardae and the exotic M. schelpeana. In fact, the habitat described for the exotic Marsilea in the platform PlantZAfrica of the South African National Biodiversity Institute is nearly the same as that for the endemic fern, which grows on seasonal pools, along watercourses or reservoirs in seasonally dry areas. It is possible that this plant has been brought by unaided pathways, such as water birds that can function as dispersal vectors across migration routes [54]. In relation to herbaceous species composition, we are aware that we cannot directly infer that the causes of biodiversity declines were solely related to the dam-induced disturbances or to LULC changes, as other factors could also contribute, such as the limited number of surveys done, the likely biased effect of sampling in two consecutive years on the post-Alqueva Dam period, and the effect of other stressors (e.g., construction of infrastructures, grazing). Nevertheless, pre- and post-dam comparisons involving both ground level surveys and aerial photographs, which were our methodologic approach, are usually complementary and compensate for some prospective limitations [55].

Our second working hypothesis was that the present-day Guadiana landscapes were more homogeneous in floristic composition and in riverine LULC. The studied zones had different floristic responses, which is likely related to the diverse hydrological alterations, including the extensive waterlogging of riparian areas, clear-cuts of riparian trees and shrubs, and geomorphologic alterations (substrate, connectivity, sediment dynamics). Presently, downstream of the dam, the landscape was more floristically diverse (increase compositional diversity), while the reservoir and upstream dam zones were more homogeneous. The riverine landscape is also more homogeneous in the post-dam period, and this is clear in the reservoir and downstream of the Alqueva Dam (reduction of landscape diversity). This pattern can be linked to the presently wetter landscape and to the loss of habitat, while 
the increase of floristic heterogeneity downstream may be associated with the maintenance of vegetation habitats on rocky substrates on the most distant core-sites downstream of the dam (Pulo do Lobo). In addition, there might be a positive effect of fragmentation on impediment of expansion of riparian herbs due to the interruption of hydrochoric dispersal, impediment of the flow of seeds, and clonal fragments downstream of the dam [56]. The successional vegetation setbacks caused by these extreme environmental abiotic changes may hamper the vegetation retrieval [49]. In addition, successful species survival on open niches of novel habitats relies on trait-filtering processes [57]. The backwater and waterlogged habitats are known to induce changes in hydrodynamics and sediment transport that could have the double effect of promoting seed germination, but also plant mortality due to hypoxia and filtering of species intolerant to prolonged inundation and large fine sediment deposition. This creates a "less diverse mosaic of riparian vegetation and animals, contrasting with those occurring in free-flowing rivers" [19]. Similar results for unaltered regional species richness for other organisms were observed in areas largely affected by continuous disturbances over time [58]. However, these large landscape changes and fragmentation likely appear to be responsible for changes in community composition and abundances $[1,50]$. In agreement with these results, studies on another biota such as birds, and dragonflies after the Alqueva Dam implementation also detected changes in abundances and composition but did not find a variation in richness totals [28,29]. In fact, changes in aquatic and riparian vegetation largely affect bird community composition in the Guadiana River, as well as many other organisms in this area $[28,59]$. For instance, bat populations were affected by the disappearance of around $200 \mathrm{~km}$ of riparian habitats of the 'old' Guadiana river, by the homogeneous habitat created by the flooded areas that can only be used for foraging in the remaining island habitats [60]. Future rainfall projections and flow simulations are not promising of better conditions for aquatic and riparian plant communities and the future of this transnational basin can be resumed as "the dry getting drier" [52]. Seasonal and annual irregularity of rainfall are also fundamental variables for the future flow projections [52], an issue of concern addressed by an early study of Suzanne Daveau published in 1977, in relation to the first construction works of the Alqueva Dam that were taking place [61]. This work let us know that for instance, at Pulo do Lobo, our most downstream core-site, annual median flows were $179 \mathrm{~m}^{3} \mathrm{~s}^{-1}$ from 1946-1947 to 1972-1973, with a large variation from the minimum flow of $14 \mathrm{~m}^{3} \mathrm{~s}^{-1}$ in 1948-1949 and $435 \mathrm{~m}^{3} \mathrm{~s}^{-1}$ in 1963-1964. Notwithstanding the above, future reductions in means and minimum flow discharges are expected, regardless of the model's uncertainties.

This study aimed to document and quantify the magnitude of impacts on vegetation and on the riverine landscape of a large reservoir in a Mediterranean river Basin. The diverse spatial levels of this approach gave synergic and complementary insights into the floristic and riverine landscape diversity. We described losses of valuable biotic resources, but we also reinforced the existence of fragmented reliquial habitats requiring restoration. We strengthen the need to restore riparian woodlands, as they are supporting diverse riverine biota. Therefore, comparing communities and species interactions under environmental changes, and the conjoint use of ecological and geomorphologic indicators [62] are needed to inform managers and professionals working in these altered landscapes.

Supplementary Materials: The following are available online at http://www.mdpi.com/2073-4441/11/11/2379/s1, Table S1: Results of chi-square homogeneity tests across functional plant groups were compared between the two periods (pre and post-dam) and for the three zones (UP=upstream of dam, RES=reservoir; Down=downstream of dam).

Author Contributions: The individual contributions of each author are as follows: conceptualization of the project, F.C.A. and M.R.F.; data collection and data curation, M.T.F., M.R.F., and F.C.A.; methodology and analysis, M.J.M., F.C.A., and M.R.F.; F.C.A. led the writing and all authors contributed to the original draft preparation.

Funding: This research received funding from the Fundação para a Ciência e a Tecnologia I.P. (FCT), Portugal, namely from the Forest Research Centre-project UID/AGR/00239/2019 and Project RIVEAL, PTDC/CTA-AMB/29790/2017. F.C.A. and M.R.F. are supported by national funds via FCT under the contracts ‘Norma Transitória'-DL57/2016/ and DL57/2016/CP1382/CT0019, respectively.

Acknowledgments: We acknowledge the Direção-Geral do Território for providing the false-color composite orthophotos from 1995. 
Conflicts of Interest: The authors declare no conflict of interest.

\section{References}

1. Angeler, D.G.; Allen, C.R.; Barichievy, C.; Eason, T.; Garmestani, A.S.; Graham, N.A.; Granholm, D.; Gunderson, L.H.; Knutson, M.; Nash, K.L.; et al. Management applications of discontinuity theory. J. Appl. Ecol. 2016, 53, 688-698. [CrossRef]

2. Grill, G.; Lehner, B.; Thieme, M.; Geenen, B.; Tickner, D.; Antonelli, F.; Babu, S.; Borrelli, P.; Cheng, L.; Crochetiere, H.; et al. Mapping the world's free-flowing rivers. Nature 2019, 569, 215-221. [CrossRef]

3. Karjalainen, T.P.; Järvikoski, T. Negotiating river ecosystems: Impact assessment and conflict mediation in the cases of hydro-power construction. Environ. Impact Assess. Rev. 2010, 30, 319-327. [CrossRef]

4. Petts, G.E. Water engineering and landscape: Prospect for environmentally sound development. In Water, Engineering and Landscape: Water Control and Landscape Transformation in the Modern Period; Cosgrove, D., Petts, G.E., Eds.; Bellhaven: London, UK, 1990; pp. 188-208.

5. Poff, N.L.; Olden, J.D.; Merritt, D.M.; Pepin, D.M. Homogenization of regional river dynamics by dams and global biodiversity implications. Proc. Natl. Acad. Sci. USA 2007, 104, 5732-5737. [CrossRef] [PubMed]

6. Nilsson, C.; Berggren, K. Alterations of Riparian Ecosystems Caused by River Regulation: Dam operations have caused global-scale ecological changes in riparian ecosystems. BioScience 2000, 50, 783-792. [CrossRef]

7. Corenblit, D.; Steiger, J.; Tabacchi, E. Biogeomorphologic succession dynamics in a Mediterranean river system. Ecography 2010, 33, 1136-1148. [CrossRef]

8. Del Tánago, M.G.; Gurnell, A.M.; Belletti, B.; De Jalón, D.G. Indicators of river system hydromorphological character and dynamics: Understanding current conditions and guiding sustainable river management. Aquat. Sci. 2016, 78, 35-55. [CrossRef]

9. Garófano-Gómez, V.; Martínez-Capel, F.; Bertoldi, W.; Gurnell, A.; Estornell, J.; Segura-Beltrán, F. Six decades of changes in the riparian corridor of a Mediterranean river: A synthetic analysis based on historical data sources. Ecohydrology 2013, 6, 536-553. [CrossRef]

10. Baxter, R.M. Environmental effects of dams and impoundments. Ann. Rev. Ecol. Syst. 1977, 8, $255-283$. [CrossRef]

11. Godinho, F.N.; Pinheiro, P.J.; Oliveira, J.M.; Azedo, R. Responses of intermittent stream fish assemblages to irrigation development. River Res. Appl. 2014, 30, 1248-1256. [CrossRef]

12. Kondolf, G.M. PROFILE: Hungry water: Effects of dams and gravel mining on river channels. Environ. Manag. 1997, 21, 533-551. [CrossRef] [PubMed]

13. Aguiar, F.C.; Segurado, P.; Martins, M.J.; Bejarano, M.D.; Nilsson, C.; Portela, M.M.; Merritt, D. The abundance and distribution of guilds of riparian woody plants change in response to land use and flow regulation. J. Appl. Ecol. 2018, 55, 2227-2240. [CrossRef]

14. Bejarano, M.D.; Nilsson, C.; Aguiar, F.C. Riparian plant guilds become simpler and most likely fewer following flow regulation. J. Appl. Ecol. 2018, 55, 365-376. [CrossRef]

15. Petts, G.E.; Morales, Y.; Sadler, J.P. Linking hydrology and biology in assessing water needs for riverine ecosystems. Hydrol. Process. 2006, 20, 2247-2251. [CrossRef]

16. Aguiar, F.C.; Martins, M.J.; Silva, P.C.; Fernandes, M.R. Riverscapes downstream of hydropower dams: Effects of altered flows and historical land-use change. Landsc. Urban Plan. 2016, 153, 83-98. [CrossRef]

17. Rivaes, R.; Pinheiro, A.N.; Egger, G.; Ferreira, M.T. The Role of River Morphodynamic Disturbance and Groundwater Hydrology as Driving Factors of Riparian Landscape Patterns in Mediterranean Rivers. Front. Plant Sci. 2017, 8, 1612. [CrossRef]

18. Fraaije, R.G.; Braak, C.J.; Verduyn, B.; Verhoeven, J.T.; Soons, M.B. Dispersal versus environmental filtering in a dynamic system: Drivers of vegetation patterns and diversity along stream riparian gradients. J. Ecol. 2015, 103, 1634-1646. [CrossRef]

19. Liro, M. Dam reservoir backwater as a field-scale laboratory of human-induced changes in river biogeomorphology: A review focused on gravel-bed rivers. Sci. Total Environ. 2019, 651, 2899-2912. [CrossRef]

20. Grabowski, R.C.; Surian, N.; Gurnell, A.M. Characterizing geomorphological change to support sustainable river restoration and management. Water 2014, 1, 483-512. [CrossRef] 
21. Brierley, G.J.; Fryirs, K.A. Geomorphology and River Management: Applications of the River Styles Framework; John Wiley \& Sons: Chichester, UK, 2013.

22. Arvela, A.S.; Panagopoulos, T.; Cakula, A.; Ferreira, V.; Azevedo, J.C. Analysis of Landscape Change Following the Construction of the Alqueva Dam, southern Portugal: Approach and Methods. In Recent Researches in Environmental Science and Landscaping; Energy, Environmental and Structural Engineering Series 2; Burley, J., Loures, L., Panagopoulos, T., Eds.; WSEAS Press: Faro, Portugal, 2012; pp. 42-47.

23. Lehner, B.; Liermann, C.R.; Revenga, C.; Vörösmarty, C.; Fekete, B.; Crouzet, P.; Döll, P.; Endejan, M.; Frenken, K.; Magome, J.K.; et al. High-resolution mapping of the world's reservoirs and dams for sustainable river-flow management. Front. Ecol. Environ. 2011, 9, 494-502. [CrossRef]

24. EDIA-Empresa de Desenvolvimento e Infra-Estruturas do Alqueva, S. EDIA, SA. Available online: http://www.edia.pt/en/ (accessed on 3 July 2019).

25. Radke, J.; Pinto, P.; Lachwani, K.; Kondlof, G.M.; Rocha, J.; Serra Lloet, A. Alqueva. Changing Ecologies of the Montado Landscape. Alentejo, Portugal; The Department of Landscape Architecture \& Environmental Planning and The Portuguese Studies Program; University of California: Berkeley, CA, USA, 2015.

26. Santos, M.J.; Pedroso, N.M.; Ferreira, J.P.; Matos, H.M.; Sales-Luís, T.; Pereira, Í.; Baltazar, C.; Grilo, C.; Cândido, A.T.; Sousa, I.; et al. Assessing dam implementation impact on threatened carnivores: The case of Alqueva in SE Portugal. Environ. Monit. Assess. 2008, 142, 47-64. [CrossRef] [PubMed]

27. Ballester-Hernández, S.; Rosselló-Graell, A.; Draper, D.; Correia, A.I.D. Monitorização de plantas prioritárias na área da albufeira do Alqueva. Linhas metodológicas. Port. Acta Biol. 2000, 19, 201-218.

28. Pereira, M.; Figueiredo, D. Effects of the Alqueva Dam Reservoir on the Distribution of Steppe Birds. Phys. Geogr. 2009, 30, 43-63. [CrossRef]

29. Fulan, J.A.; Raimundo, R.; Figueiredo, D.; Correia, M. Abundance and diversity of dragonflies four years after the construction of a reservoir. Limnetica 2010, 29, 279-286.

30. Morais, P. Review on the major ecosystem impacts caused by damming and watershed development in an Iberian basin (SW-Europe): Focus on the Guadiana estuary. Ann. Limnol. Int. J. Limnol. 2008, 44, 105-117. [CrossRef]

31. Chícharo, M.A.; Chícharo, L.; Morais, P. Inter-annual differences of ichthyofauna structure of the Guadiana estuary and adjacent coastal area (SE Portugal/SW Spain): Before and after Alqueva dam construction. Estuar. Coast. Shelf Sci. 2006, 70, 39-51. [CrossRef]

32. Morais, M.M.; Serafim, A.M.; Pinto, P.; Ilhéu, A.; Ruivo, M. Reservoir and River Basin Management. Exchange of Experiences from Brazil, Portugal and Germany. In Monitoring the Water Quality in Alqueva Reservoir, Guadiana River, Southern Portugal; Gunkel, G., Sobral, M., Eds.; Technical University of Berlin: Berlin, Germany, 2007; pp. 96-113.

33. Palma, P.; Alvarenga, P.; Palma, V.; Matos, C.; Fernandes, R.M.; Soares, A.; Barbosa, I.R. Evaluation of surface water quality using an ecotoxicological approach: A case study of the Alqueva Reservoir (Portugal). Environ. Sci. Pollut. Res. 2010, 17, 703-716. [CrossRef]

34. Ferreira, T.; Monteiro, A. Estudo das comunidades de macrófitos aquáticos do rio Guadiana. Actas Col. Ecol. Bacias Hidrogr. Rec. Zoológicos 1988, 129-137.

35. Capelo, J. Esboço da paisagem vegetal da bacia portuguesa do rio Guadiana. Silva Lusit. 1996, 4, $13-64$.

36. Ferreira, M.T.; Godinho, F.N.; Cortes, R.M. Macrophytes in a southern Iberian river. Int. Ver. Theor. Angew. Limnol. Verh. 1998, 26, 1835-1841. [CrossRef]

37. Rosselló-Graell, A.; Draper, D.; Tauleigne Gomes, C.; Correia, A.I.D. Marsilea batardae Launert em Portugal e determinação do seu estatuto de ameaça. Port. Acta Biol. 2000, 19, 219-224.

38. Ferreira, M.T.; Albuquerque, A.; Aguiar, F.C.; Catarino, L.F. Seasonal and yearly variations of macrophytes in a Southern Iberian River. Int. Ver. Theor. Angew. Limnol. Verh. 2001, 27, 3833-3837. [CrossRef]

39. Ferreira, M.T.; Albuquerque, A.; Aguiar, F.C.; Sidorkewicz, N. Assessing reference sites and ecological quality of river plant assemblages from an Iberian basin using a multivariate approach. Arch. Hydrobiol. 2002, 155, 121-145. [CrossRef]

40. Aguiar, F.C.; Ferreira, M.T.; Albuquerque, A. Patterns of exotic and native plant species richness and over along a semi-arid Iberian river and across its floodplain. Plant Ecol. 2006, 184, 189-202. [CrossRef]

41. Draper, D.; Marques, I.; Iriondo, J.M. Species distribution models with field validation, a key approach for successful selection of receptor sites in conservation translocations. Glob. Ecol. Conserv. 2019, 19, e00653. [CrossRef] 
42. Portuguese Environment Agency (APA). Plano de Gestão de Região Hidrográfica. Parte 2-Caracterização e Diagnóstico. Região Hidrográfica do Guadiana (RH7); APA: Amadora, Portugal, 2016.

43. Neto, S. Alqueva dam in the Guadiana River Basin-Past and future of illusive water abundance. Water Policy 2019, 5, 71-84. [CrossRef]

44. Aguiar, F.C.; Ferreira, M.T.; Albuquerque, A.; Moreira, I. Alien and endemic flora on reference and non-reference sites from Mediterranean type-streams of Portugal. Aquat. Conserv. Mar. Freshw. Ecosysyst. 2007, 17, 335-347. [CrossRef]

45. Franco, J.A.; Rocha-Afonso, M.L. Nova Flora de Portugal (Continente e Açores). 3(1) Alismataceae-Iridaceae; 3(2) Gramineae; 3(3) Juncaceae-Orchidaceae; Escolar Editora: Lisbon, Portugal, 1994.

46. Christenhusz, M.; Lansdown, R.V.; Bento Elias, R.; Dyer, R.; Ivanenko, Y.; Rouhan, G.; Rumsey, F.; Väre, H. Marsilea batardae. The IUCN Red List of Threatened Species 2017; E.T161966A85434785; International Union for Conservation of Nature and Natural Resources: Cambridge, UK, 2019.

47. Victor, J.E.; Dold, A.P. Marsilea schelpeana. The IUCN Red List of Threatened Species 2010; E.T185228A8371113; International Union for Conservation of Nature and Natural Resources: Cambridge, UK, 2019.

48. Lavorel, S. Ecological diversity and resilience of Mediterranean vegetation to disturbance. Divers. Distrib. 1999, 5, 3-13. [CrossRef]

49. Fraaije, R.G.; Braak, C.J.; Verduyn, B.; Breeman, L.B.; Verhoeven, J.T.; Soons, M.B. Early plant recruitment stages set the template for the development of vegetation patterns along a hydrological gradient. Funct. Ecol. 2015, 29, 971-980. [CrossRef]

50. Su, X.; Polvi, L.E.; Lind, L.; Pilotto, F.; Nilsson, C. Importance of landscape context for post-restoration recovery of riparian vegetation. Freshw. Biol. 2019, 64, 1015-1028. [CrossRef]

51. Guerreiro, S.B.; Birkinshaw, S.; Kilsby, C.; Fowler, H.J.; Lewis, E. Dry getting drier-The future of transnational river basins in Iberia. J. Hydrol. Reg. Stud. 2017, 12, 238-252. [CrossRef]

52. Canuto, N.; Ramos, T.B.; Oliveira, A.R.; Simionesei, L.; Basso, M.; Neves, R. Influence of reservoir management on Guadiana streamflow regime. J. Hydrol. Reg. Stud. 2019, 25, 100628. [CrossRef]

53. Brandt, S.A. Classification of geomorphological effects downstream of dams. Catena 2000, 40, 375-401. [CrossRef]

54. Reynolds, C.; Miranda, N.A.; Cumming, G.S. The role of waterbirds in the dispersal of aquatic alien and invasive species. Divers. Distrib. 2015, 21, 744-754. [CrossRef]

55. Braatne, J.H.; Rood, S.B.; Goater, L.A.; Blair, C.L. Analyzing the impacts of dams on riparian ecosystems: A review of research strategies and their relevance to the Snake River through Hells Canyon. Environ. Manag. 2008, 41, 267-281. [CrossRef]

56. Rood, S.B.; Braatne, J.H.; Goater, L.A. Favorable fragmentation: River reservoirs can impede downstream expansion of riparian weeds. Ecol. Appl. 2010, 20, 1664-1677. [CrossRef]

57. Larson, J.E.; Funk, J.L. Regeneration: An overlooked aspect of trait-based plant community assembly models. J. Ecol. 2016, 104, 1284-1298. [CrossRef]

58. Parody, J.M.; Cuthbert, F.J.; Decker, E. The effect of 50 years of landscape change on species richness and community composition. Glob. Ecol. Biogeogr. 2001, 10, 305-313. [CrossRef]

59. Godinho, C.; Rabaça, J.E.; Segurado, P. Breeding bird assemblages in riparian galleries of the Guadiana River basin Portugal-The effect of habitat structure and habitat variables. Ecol. Res. 2010, 25, 283-294. [CrossRef]

60. Rebelo, H.; Rainho, A. Bat conservation and large dams: Spatial changes in habitat use caused by Europe's largest reservoir. Endanger. Species Res. 2009, 8, 61-68. [CrossRef]

61. Daveau, S. Bases geográficas do problema da barragem de Alqueva. Finisterra 1977, 12, 342-351. [CrossRef]

62. Stallins, J.A.; Corenblit, D. Interdependence of geomorphic and ecologic resilience properties in a geographic context. Geomorphology 2018, 305, 76-93. [CrossRef]

(C) 2019 by the authors. Licensee MDPI, Basel, Switzerland. This article is an open access article distributed under the terms and conditions of the Creative Commons Attribution (CC BY) license (http://creativecommons.org/licenses/by/4.0/). 